\title{
The Right to Basic Education in South Africa: Lessons from Section 27 and Others v Minister of Education and Another (2012) ZAGPPHC 114
}

\author{
Mashele Rapatsa \\ PhD student, University of Groningen, Globalisation Studies and Humanitarian Action, Netherlands, Lecturer, \\ Faculty of Management and Law, Department of Mercantile and Labour Law, \\ University of Limpopo (Turfloop Campus), South Africa \\ Email:m.j.rapatsa@rug.nl \\ Nicholas Matloga \\ Commissioner, CCMA, Polokwane, South Africa \\ Email: nicholasmatloga@gmail.com
}

Doi:10.5901/mjss.2014.v5n27p1120

\begin{abstract}
This article proffers a critical discussion on the right to basic education in South Africa. It argues that access to basic education is society's crucial developmental aspect. Further that minimal or lack of commitment and respect for education largely impact adversely on the realization of Millennium Development Goals, and constitute a recipe for disaster in any country. The article is a product of distress subsequent to a dismal experience resultant from a failure by Limpopo Department of Basic Education to honour and carry out its obligations of providing and delivering textbooks. Provision of textbooks to schools constitute state's non-derogable duty which is indispensable in reinforcing the transformative ideals of the Constitution, that aid the commitment of realizing the right to basic education and uplifting societal literacy. It is argued that nationwide workshops and campaigns ought to be carried out in view of propagating for respect, care and commitment to deliver quality basic education to the populace. Further that there exists a desperate need for a reinforced system that ensures quality leadership and accountability for the progressive realization of this essential right. The South African Constitution, other legislation, international instruments, articles and case law were utilized in the completion of this article.
\end{abstract}

Keywords: right to basic education, socio-economic right, textbooks delivery, transformation, development

\section{Introduction}

"Education is the great engine of personal development. It is through education that the daughter of a peasant can become a doctor; that a son of a mine worker can become head of the mine; that a child of a farm worker can become the president of a great nation. It is what we make out of what we have, not what we are given, that separates one person from another" Nelson Mandela.

Education has embedded its universal legacy as a human rights issue. In terms of section 29(1)(a) \& (b), the Constitution of the Republic of South Africa, 1996 (hereinafter referred to as 'the Constitution') guarantees everyone the right to basic education, and other related socio-economic rights in section 27. This promise accords particularly with Article 1(1) of the World Declaration on Education for All adopted during 1990 in Thailand. Protection of the right to education also finds proponents in revered international instruments, inclusive of; Article 26 of the Universal Declaration of Human Rights of 1948; Articles 13 and 14 of International Covenant on Economic, Social and Cultural Rights of 1996; Articles 28 and 29 of the UN Convention on the Rights of the Child of 1989 and Article 2 of Protocol No.1 to the European Convention for the Protection of Human Rights and Fundamental Freedoms of 1953. Thus, it is trite and generally accepted that education is prime to success and that the future of any country is largely contingent on children receiving quality basic education. Lack of access to basic education result in severe social disinvestment that compromises development of skills and knowledge necessary for children to make significant contribution in the society (Holgado, 2014). Definitely, this entails that there are major social, economic and political benefits that come with an educated populace (Simbo, 2012). It plays a crucial role in the development of human personality, creativity and society's sustainable development in whole. In Section27 and Others $v$ Minister of Education and Another (24565/2012) [2012] ZAGPPHC 114: at Para 3, Kollapen J articulated that 'education is critical in both freeing and unlocking the potential of every individual. This resonates with the 
transformative ideals of the Constitution. In its Annual Performance Plan for the year 2011 to 2012, the Limpopo Department of Education reiterated one of its goals, and thus, to ensure that every learner has access to a minimum set of learning materials, including text books and work books required according to National Policy.

The curriculum strategy of the Department, dated March 2011 also resonates that, the availability and retention of learning support materials is a vital ingredient in the delivery of quality learning and teaching. When resources such as learner and teacher support materials are insufficient, teachers experience great difficulty in planning and conducting lessons, even where there were enough other resources. Clearly the above provides correctly, the unambiguous stance by Government that text books are an essential and vital component in delivering quality learning and teaching in our educational system.

It is against this backdrop that this article seeks to reflect on the ostensible violation of this constitutional right. It also reflects on how the Limpopo Department of Education violated the aforesaid right. The article is cognisant of the judgment delivered by Kollapen $\mathrm{J}$ in Section27 and Others $v$ Minister of Education and Another. Of importance, this it reflects on the right to basic education guided significantly by the entrenched constitutional provisions and international instruments propagating unhindered access to education.

\section{Methodology}

This article does a qualitative study and is primarily concerned with studying the application, enforcement and realization of the right to basic education. The article is both descriptive and exploratory. It utilizes content analysis method premised on studying laws, policies and other scholarly texts. A case of Section27 and Others v Minister of Education and Another is relied upon.

\section{Insights into Section 27 Case}

On the $5^{\text {th }}$ December 2011, the national government placed the poorly performing provincial governments under administration in accordance with section 100(1)(b) of the Constitution and section 216 of Public Finance Management Act 1 of 1999. Limpopo province was amongst them. The provisions as stated above authorize the national government to step in if a province fails and continue to fail in fulfilling its constitutional obligations. Placing the province under administration affected various departments, including that of education. Resultant thereto, there was a widespread crisis of lack of provisioning of books to schools in the province. The most affected learners were grades R, 1, 2, 3 and 10.

Basic Education Minister, Angie Motshekga had to intervene to rescue the situation. Section 100(1)(b) thus provides in part that;

"When a Province does not or cannot fulfill an executive obligation in terms of the Constitution or legislation, the National Executive may intervene by taking any appropriate steps to ensure fulfillment of that obligation including maintaining essential national standards or meeting established minimum standards for the rendering of a service."

Through her intervention, the Minister evinced that all schools will receive their foundation phases and Grade 10 text books when they reopened for the third term. Motshekga also announced the roll-out of the 'catch-up plan' which was aimed at ensuring that foundation phase and Grade 10 learners get to grips with the content they missed during the first and second terms as a result. Motshekga also announced a spring camp for Grade 12 pupils to ensure they are well prepared for the year-end exams. The Minister set up a call centre for Limpopo schools which had not received their textbooks. Addressing the media at the Greenside Primary School in Polokwane (Limpopo), Motshekga said teachers and principals can use the hotline to inform the department if they have not received their books consignments. Despite the Minister's intervention, less was achieved. The Intervention Team was established to investigate the procurement process and the failures in this regard. Despite several promises, the team also failed to order and deliver textbooks. Section27 (an NGO) repeatedly engaged with the Department and the national government on this issue, but to no meaningful consequences.

On the $4^{\text {th }}$ May 2012, Section27 together with Hanyani Thomo Secondary School and Tondani Lydia Masiphephethu of Giyani, lodged an urgent application with the North Gauteng High Court, Pretoria, asserting that the Department of education has a Constitutional obligation to fulfill the right to basic education which duty, includes amongst others, the provision of text books and that the failure by the respondents to provide such text books to schools in Limpopo at the commencement of the school year or within a reasonable period thereafter, constituted a violation of the right to basic education and the South African Schools Act 84 of 1996. The applicants further sought an order directing 
the Department of Basic Education and the Limpopo Department of Education:

- To provide textbooks to learners throughout Limpopo who have been without textbooks since the commencement of the academic year by no later than the 31 May 2012; and

- To put in place a 'catch-up' plan to provide additional classes to learners until their lost curriculum is recovered.

The Court held that indubitably, the failure by the department to provide text books, constituted a violation of right to basic education (Section27: at Para 32). Accordingly, the court ordered the Department to provide text books for Grades R, 1, 2, 3 and 10 on an urgent basis, commencing on 31 May 2012 and concluding by no later than 15 June 2012. Further, the Department was ordered to immediately develop a 'catch-up/remedial' plan for affected Grade 10 learners in Limpopo (Section27: at Para 43).

Despite the court order, the department still failed to adhere to the time limits. Due to widespread media coverage, the matter attracted a huge public outcry. Nobel literature prize winner Nadine Gordimer, who had several works banned by the apartheid regime, said 'Our education system is a wreck. It's a shamble. I cannot believe that three-quarters of the year have gone by and so many of our schools, especially in the rural areas, have been without textbooks'.

The NEC of the African National Congress (ANC) also acknowledged that a failure to deliver textbooks in Limpopo constituted a grave concern. Speaking to reporters in Johannesburg, the party's Secretary General Gwede Mantashe indicated that 'the NEC considered the lack of delivery of books in Limpopo as shocking and unacceptable and believes that whosoever is found to be responsible must face stern action that may include criminal charges'.

\section{The Right to Basic Education and Transformation: Why Section27 Case Matters?}

South Africa's past underlie the broader societal efforts on transformation agenda. This includes on matters of access to basic education in general. It is worth noting that the devastating past of apartheid education system despised societal educational imperatives, human dignity, capacity to be creative and development (Yamauchi, 2005; Nelson Mandela Foundation, 2005; Dept. of Education, 2003). Within this context, the Constitutional Court asserts that an ideal transformative model should be that which epitomizes focus on the needs of disadvantaged learners first, before extension to the privileged groups (Arendse, 2011). Hence, a host of policies with strong equity focus remain a necessity to cater for children in rural areas (SA Human Rights Commission, 2012), the only contrivance that can mitigate the effects of history.

At the dawn of South Africa's democracy in 1994, the right to basic education found constitutional entrenchment amongst the fundamental rights (Section 32(a) in the interim Constitution, Act No. 200 of 1993). This was aimed at complimenting social, economic and political strategies of integrating all South Africans, especially the previously marginalized people, into a collective hub of facilitating economic growth and sustainable development (Spaull, 2013; Yamauchi, 2005). Because the right to education encompasses first (civil and political rights), second (socio-economic rights) and third (development, environment, self-determination rights and so forth) generations of rights, the legislature deemed it indispensable to also feature this essential right in the final Constitution. In the aftermath, this obligated the state to promulgate laws and develop policies to protect, respect, promote and fulfil this right (Lake and Pendlebury, 2009). This was considerate of strengthening the societal transformative ideals, by recognizing the importance of education in transforming the society. The Constitution thus provides in section 29 that;

(1) Everyone has the right -

(a) to basic education, including adult basic education; and

(b) to further education, which the state, through reasonable measures, must make progressively available and accessible.

The explicit constitutional entrenchment founded a greater regard for this right and a solid constitutional duty on the state. If this right was not so quintessential, there would not have been justification of its inclusion in the final Constitution. As Kollapen J (Section27, at Para4) put it, the right to education is recognized both as an important policy imperative that Government has committed itself to, as well as a central and interlocking right in the architecture of the rights framework in the Constitution. In this regard, the preamble to the Constitution contains a commitment to improve the quality of life of all citizens and free the potential of each person. This is achievable through education.

Therefore, to give effect to the right to basic education, the government promulgated South African Schools Act 84 of 1996. This Act in part aims to strengthen a provision of a uniform system for the organisation, governance and funding of schools in the country to ensure a comprehensive realization of this right. The right to basic education is however not a stand-alone right. An enhanced rights framework recognizes this right as a means through which other rights are realized (Spreen and Vally, 2006). In order to achieve its meaningful realization, the right necessitates the need to enhance 
various other areas. This includes areas such as infrastructure, learner transport, security at schools, nutrition and such related matters. This entails that when the right to basic education is realized, this amounts to substantive freedom which enables enjoyment of other rights. Nonetheless, because of its nature, the right is distinguishable from other socioeconomic rights. In this regard Kollapen J made reference to the Governing Body of the Juma Masjid Primary School \& another v Essay N.O 2011 (8) BCLR (CC): at Para 37. As per Justice Nkabinde, 'unlike other socio-economic rights, the right to basic education ought to be instantly realized by everyone. There is no internal limitation requiring that the right be progressively realized within available resources subject to reasonable legislative measures. The right to basic education in Section 29 (1)(a), may be limited only in terms of the law of general application which is reasonable and justifiable in an open and democratic society considerate of aspects such as human dignity, equality and freedom. This right is therefore distinct from the right to further education as provided in Section 29 (1)(b). In this regard, the state is obliged through reasonable measures to make further education progressively available and accessible'. Accordingly, the case of Section27 corroborates that an obligation existed on the part of the Department and state to ensure the immediate realization of the right to basic education. It is discernible in this regard that Kollapen J share correlating sentiments with Daniel Brand and Christof Heyns (2005) who argued that education is necessary for the enjoyment of other rights and freedoms in the Constitution.

According to Klaus Dieter Beiter (2006), a trend has emerged of not defining education as a human right anymore, but of rather calling it a human need. This has paved the way for an ever increasing commercialisation of education, excluding or limiting the impoverished segments of the society from accessing quality education. A problem at a different level is that states often do not know what is expected of them when advancing the right to education as protected by international law. This relates to the complex nature of this right, which is simultaneously a civil and political and an economic, social and cultural right in all instances. Beiter further adds that education is an interactive process which involves learning, and that merely attending educational institutions without learning anything, does not amount to education, hence the right to education must therefore be understood in the sense of a right to be educated. The interpretation given by Beiter would be that, it will be meaningless attending school with no material that support effective learning. In this regard, textbooks and other working books are an essential element amongst components that Beiter argues about. Indeed, textbooks are essential for learning as Kollapen J (Section27, at Para 25), reiterated that the provision of learner support material in the form of textbooks, as may be prescribed is an essential component of the right to basic education and its provision is inextricably linked to the fulfillment of the right. In fact, it is difficult to conceive, even with the best of intentions, how the right to basic education can be given effect to in the absence of text books.

In addition, it is asserted that as part of socio-economic rights, the right to basic education is closely linked to rights to equality, health care services, sufficient food and water, social security, shelter, basic health care services and other social services. To that effect, the Constitution, positively instructs that in every matter including but not limited to education, the best interests of the child are of paramount importance. This entails that the government must ensure that it allocates necessary resources in an effort to prioritizing and advancing the best in interest of all learners as aspired by the Convention on the Rights of the Child, 1989. The Section27 case demonstrates that courts continue to play an important oversight role by instructing government to give full effect to all rights in the Bill of Rights. The case also shows that lack of political will is a major obstacle in the advancement of meaningful change for shaping societal developments.

\section{The International Protection of the Right to Basic Education}

An extensive dialogue and recognition of the right to basic education has not been limited only to South African discourse. Indeed, it has and continues to receive significant attention at the international level too. The international community shares a revered collective commitment to realizing the right to basic education world over. As evinced, this right enjoys extensive protection at international law and indeed rhymes its importance through various international instruments. Its official inclusion on the international agenda dates back into the founding of the Universal Declaration of Human Rights (UDHR, 1948). The UDHR embedded the right to education in article 26. To date, this remains a foundational norm with regards to the right to education across all sectors in the international sphere. It is for this reason that the right to (primary) education was given explicit expression in the Millennium Development Goals (MDGs), MDG-2 in particular. Apart from the UDHR, there is an array of other international instruments giving effect to this right. This is inclusive of, amongst others, International Covenant on Economic, Social and Cultural Rights (ICESCR, 1966), which obligates states to make primary education compulsory and free in Article 13(2). Other instruments include, the Convention on the Elimination of all Forms of Discrimination against Women (CEDAW, 1979), World Declaration on Education for all 1990, UNESCO Convention against Discrimination in Education, 1960 (CDE), Convention on the Rights of the Child, 1989 and Protocol No.1 of the European Convention for the Protection of Human Rights and Fundamental 
Freedoms, which provides that no person shall be denied the right to education. South Africa ratified most of the fundamental international instruments. Therefore, government of any country that is party to any of these essential instruments is obligated to act in a manner that support and advances the right to basic education. This entails that the government must interpret and honor the right to basic education in line with international law and the democratic values in an open and free society. There ought to be respect, protection and promotion of the right as entrenched in the both domestic legislation and policies, and international laws. Further, section 39 (1)(b) of the Constitution obligates the courts, tribunals and other forums to have regard for international law when interpreting any constitutional provisions and any other domestic laws. This is at the instance where international law may transcend national laws.

Commenting on the importance of international protection of the right to basic education, Kollapen $\mathrm{J}$ (Section27, at Para 27) reasoned that, 'most societies, South Africa included, place a high premium on education. Not only is it the means by which individuals are able to fulfill their potential, it also provides in a wider sense the basis for development and upliftment. Accordingly in the context of International Human Rights Law, and increasingly in the context of National Legal Systems, it is not a privilege but a right, creating with it duties and obligations and where the right is violated, activating the need to craft appropriate remedies thereto'.

As Douglas Houdgson (1998) put it, the international community appears to certainly have a fairly comprehensive and detailed set of human rights norms in the educational field. This is a reality given a set of international and regional instruments that have been put in place to reinforce the broader achievement of the right to education. Within the same context, it is worth noting that the international community still faces critical challenges with regards to effective implementation of the existing measures that seek to bridge the gap between the international obligations undertaken by nations and the performance of their governments in fulfilling them. From this passage, it is discernible that there was very little that the people could do in Section27 case, except approaching the court of law to compel the Department to deliver the textbooks. In this regard, it is important to indicate that as a member state to essential international instruments, South Africa not only owes it obligation in terms of respecting, protecting and promoting the right to education, but it also owes its fundamental duty to the international community with regards to observing obligations as imposed by these international conventions, and of course the comprehensive set of domestic legislative and policy measures.

\section{Calibrating the Future: Prospects}

Undeniably, South Africa comes from a protracted history of unjust educational systems, struggles over quality basic education, health care services and social security among others (Liebenberg and Pillay, 2000). Thus, the persistent educational challenges and widespread inequalities are partly attributable to the legacy of apartheid, which officially implemented the race-based education system after 1948 (Berger, 2003), lasting for subsequent 46 years.

However, it cannot be correct to continuously blame apartheid even for unambiguous failures on our part. Section27 case demonstrates unequivocally. At the advent of democracy, a better life for all, became envisaged as a beacon of hope. But, there cannot be a better life without access to quality education. The slogan was adopted by the ANC symbolizing an agenda of transforming the country from the worst to better, where all live in peace, dignity, equality and with freedoms. That education was amongst the prioritized areas is not in dispute. Access to quality basic education is therefore an essential constituent in the preservation of human dignity.

Today, common experiences by ordinary people reveal stark contrast and somehow similarities, between the past and present. It then leaves us asking, what does it mean when a democratically elected government (through its functionaries) infringes the right to basic education? While it is acknowledged that South Africa's efforts of legitimately advancing access and enjoyment of the right to basic education have been impressive in terms of policy and legislative initiatives, it should also be noted that the same has been accompanied by critical challenges. The societal social problems cannot be understated in this regard. This includes aspects of enforcement and tangible realization thereto, against widespread levels of poverty (Frye, 2013; Treasury Budget Review, 2013) and spiraling inequalities between the rich and the poor (Mattes, 2012; Appolis and McKinley, 2009). Therefore, this entails that there ought to be concrete appreciation of issues of reality, legal initiatives and obligations imposed by them, and in principle, public perception with regards to what is considered the best education for children. Thus, ensuring swift enforcement of the right is significant as it assists in translating the constitutionally entrenched right into reality. The most critical question therefore is how the state can ensure that every child including those in the country's most disadvantaged communities have access to the best quality education available? In terms of section 29 , the state is obligated to provide proper basic and further education. In the absence of progressive interpretations on what would constitute minimum standards for state to fulfill its obligations, it is asserted that the state must ensure that the provisioning of education is in accordance with the 
democratic ideals and aspirations. This is primarily important as it guides the process of asserting and exercising such rights as the right to basic education.

Aspects of enforcing the right to basic education find proponents in some landmark jurisprudence. For instance, in S v Makwanyane 1995 (3) SA (CC): p156. Ackermann J characterised the new constitutional order in the following terms:

\begin{abstract}
"We have moved from a past characterised by much which was arbitrary and unequal in the operation of the law to a present and a future in a constitutional State where State action must be such that it is capable of being analysed and justified rationally. The idea of the constitutional State presupposes a system whose operation can be rationally tested against or in terms of the law. Arbitrariness, by its very nature, is dissonant with these core concepts of our new constitutional order."
\end{abstract}

South Africa's educational settings are characterized by a dual system comprising of private and public schools. Because the majority of people in South Africa are still ravaged by poverty, public schools remain their only hope and salvation in terms of realizing the right to basic education. Thus, a poor state in which most public schools remain is a major concern, as Peace Nobel Prize Winner, Archbishop-Emeritus Mpilo Desmond Tutu put it (Gordimer, 2012). The dimension of this aspect is that it impact badly on efforts to proliferating progressive realization of this right. Within this context, it is essential to critique the impact of dual-education system. That is, a private-public schools setting. This is necessarily because very often than not, admission to private schools have been found to embody access to a better basic education when compared to public schools. This is an aspect which links directly with aspects of better resources and facilities, qualified and committed staff and other personnel and issues of infrastructure. This then prompts debates on political will aspects in it as most of politicians take their children to private schools while the majority of poor children in the rural areas are subjected to poorly functioning public schools. Hence, where there is lack of political will, state services crumbles and eventually collapses.

It is essential that issues pertaining realization of this right should be within an established framework. That is, we have to first understand what it means by basic education and how to realize it. Notably, the right to basic education establishes both positive and negative obligations on the state. Positive obligation in the sense that it requires state to put in place, measures and take steps to ensure that every child has access to educational facilities and enjoys the right fully. Negative obligation pertains the fact that government must refrain from interfering or obstructing enjoyment of the right. Therefore, education ought to be available and accessible. The Section27 case demonstrates that in both instances, the state has failed to discharge its obligations.

\title{
7. Conclusion
}

It is clear that the Constitution safeguards the right to basic education. However, its meaningful realization is yet to be achieved (Modisaotsile, 2012; Simbo, 2012; Christie, 2010; Berger, 2003 ). A greater challenge is on translating this right into reality considering the vast lack of resources. Aspects of these resources range from skills and leadership, infrastructure, funds and other facilities. Section27 case is a prime example. Notwithstanding all these, the obligation remains intact on the state to harness efforts in the realization of the right to basic education. In this regard, this emphasizes the need to countenance best interests of the child to transcend every aspect on matters that concern children's education. The best interests of the child are best served when such a child is given quality basic education. This was reiterated in Laerskool Middelburg v Departementshoof Mphumalanga Departement van Onderwys 2003 (4) SA 160 (T), at 178C and Du Toit v Minister of Welfare and Population Development 2003 (2) SA 198 (CC) at 201G to 202A. Thus, access to basic education is amongst the fundamental pillars that invariably determine the sustainability of South Africa's transformative agenda and development. Without a progressive access to quality basic education, the country's chances of realizing a meaningful change in broader socio-economic orientations diminishes. It is highly imperative for all spheres of government (local, provincial and national) to commit and ensure access to basic education as a guaranteed right. But, moving forward a workable solution could be contingent on establishing a framework which shall regulate and describe in clear terms what constitute basic education. This will ensure compatibility in both public and private schools. To achieve this, absolute political will is quite indispensable and is the prime remedy.

\section{References}

Appolis, J. \& McKinley, D. (2009). Movement-Building: The Capitalist Crisis and the South African Elections. Pampazuka. Issue 428. [Online] Available: http://www.pampazuka.org/en/category/comment/55635 (August 14, 2014).

Arendse, L. (2011). The Obligation to Provide Free Basic Education in South Africa: An International Law Perspective. Potchefstroom 
Electronic Journal, 14:6, 97-127.

Berger, E. (2003). The Right to Education Under the South African Constitution. Columbia Law Review, 103, 604-661.

Brand, D. \& Heyns, C. (2005). Socio-Economic Rights in South Africa, Cape Town: ABC/University of Pretoria Law Press.

Christie, P. (2010). The complexity of human rights in global times: The case of the right to education in South Africa. International Journal of Education Development, 30, 3-11.

Frye, I. (2013). Policy Brief 2: Towards a decent living level. Studies in Poverty and Inequality Institute, 1 - 11.

Hodgson, D. (1998). The human right to education. United Kingdom: Dartmouth Publication Co.

Lake, L. \& Pendlebury, S. (2009). Children's right to basic education. South African Child Gauge Children's Institute: UCT. 2,19-23.

Liebenberg, S. \& Pillay, K. (eds.). (2000). Socio-Economic Rights in South Africa: A Resource Book, Socio-Economic Rights Project. Community Law Centre, University of the Western Cape.

Mattes, R., (2012). The 'Born-Frees': The Prospects for Generational Change in Post-apartheid South Africa. Australian Journal of Political Science, 47, 133 - 153.

Modisaotsile, B.M. (2012). The Failing Standard of Basic Education in South Africa. Africa Institute of South Africa, Briefing No. $72,1-7$.

National Treasury, (2013). Treasury Budget Review: Social security and social wage, South Africa. [Online] Available: http://www. treasury.gov.za/documents/national\%20budget/2013/review/FullReview.pdf (August 18, 2014).

Nelson Mandela Foundation, (2005). Reflections on Ten Years of Basic Education: Challenges

To the Transformation of Basic Education in South Africa's Second Decade of Democracy. [Online] Available: http://www.nelsonmandela .org/uploads/files/Reflections-on_ten_years_of_basic_education_(PDF).pdf (August 25, 2014).

SAPA, (2012), Nadine Gordimer slams South Africa's education system. [Online] Available: http://mg.co.za/article/2012-07-31-nadinegordimer-slams-south-africas-education-system (August 27, 2014).

Simbo, C. (2012). Defining the term basic education in the South African Constitution: An Internatinal law approach. Law, Democracy and Development, 16, 162-184.

South African Human Rights Commission, (2012). The right of children to basic education.

Charter on Children's Basic Education Rights. [Online] Available: http://www.sahrc.org.za/home/21/files/SAHRC\%20Education\%20 Rights\%20Charter_Part1.pdf (August 28, 2014).

Spaull, N. (2013). Poverty and privilege: Primary school inequality in South Africa. International Journal of Education Development, 33 , 436-447.

Spreen, C.A. \& Vally, S. (2006). Education rights, education policies and inequality in South Africa. International Journal of Education Development, 26, 352-362.

Yamauchi, F. (2005). Race, equity and public schools in post-Apartheid South Africa: Equal opportunity for all kids. Economics of Educations Review, 24, 213-233. 